\title{
MODELS TO FORECAST REVENUE OF FAST FOOD RESTAURANTS
}

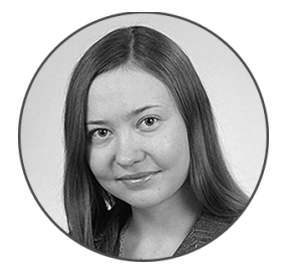

\author{
Ekaterina B. GRIBANOVA
}

Tomsk State University of Control Systems and Radioelectronics, Tomsk, Russian Federation

katag@yandex.ru

Corresponding author

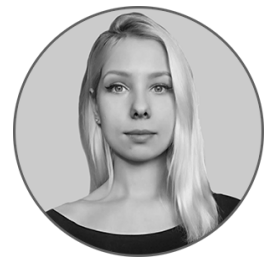

\section{Ekaterina S. SOLOMENTSEVA}

Tomsk State University of Control Systems and Radioelectronics, Tomsk, Russian Federation katerinkas_1995@mail.ru

\section{Article history:}

Received 26 January 2018

Received in revised form

5 February 2018

Accepted 22 February 2018

Translated 13 June 2018

Available online 27 June 2018

JEL classification: $\mathrm{C} 22, \mathrm{C} 53$

Keywords: forecasting, revenue, regression model,

fast food restaurant, outlying case

\begin{abstract}
Importance The article addresses changes in revenue of fast food restaurants.

Objectives The research develops and investigates models for forecasting revenue of fast food restaurants, considering the specifics of operations, changes in revenue on week days and holidays.

Methods We apply methods for statistical processing of findings and a regression analysis. We have built an autoregressive model, seasonality- and trend-specific model and a trend based on grouped data. The model parameters are evaluated by the least squares method.

Results We use data for two years' time to build three regression models to predict corporate revenue during business days, evaluate errors and significance of equations. To forecast the amount of revenue during holidays, we devised an algorithm to select a group of data that corresponds to a certain day of the week based on the analysis of outlying cases. We also present a case study on forecasting the revenue on a holiday, using the developed algorithm. The results of the analysis may be useful to study financial performance of fast food restaurants.

Conclusions and Relevance We suggest using different models to forecast revenue on holidays and other days. Our experiments show that this approach contributes to more precise forecast of revenue.
\end{abstract}

(c) Publishing house FINANCE and CREDIT, 2018

The editor-in-charge of this article was Irina M. Vechkanova

Authorized translation by Irina M. Vechkanova

Revenue is a key performance indicator of any firm. It is of paramount importance for any business to identify and forecast how their revenue will behave in the future so as to manage their income and expenditures, thus ultimately defining the effectiveness. To assess the indicator, we used such methods as exponential

${ }^{\dagger}$ For the source article, please refer to: Грибанова Е.Б., Соломенцева Е.С. Модели прогнозирования выручки ресторана быстрого питания. Экономический анализ: теория и практика. 2018. T. 17. № 4. C. 754-767.

URL: https://doi.org/10.24891/ea.17.4.754 smoothing, moving average, regression analysis, factor analysis. The article also discusses some proceedings on revenue forecasting.

N.P. Lyubushin and N.E. Babicheva [1] approach to forecasting the tourist agency's revenue in terms of seasonality. The time interval expansion method, moving average and trends models are used to evaluate the way this indicators changes.

Please cite this article as: Gribanova E.B., Solomentseva E.S. Models to Forecast Revenue of Fast Food Restaurants. 
Based on performance results of a company specializing in sale of truck tires and wheels, N.N. Odiyako, N.Yu. Golodnaya [2] constructed an additive and multiplicative model which features levels of time series as the sum of trend, seasonal and random components.

Indeed, L.R. Weatherford, S.E. Kimes [3] compared methods for hotel revenue forecasting, i.e. exponential smoothing, moving average, linear and logarithmic regression reflecting a correlation between the number of rooms booked at a certain point of time in the future and the number of rooms books at the current moment. They also examined an additive and multiplicative pickup-models showing how many rooms booked at a certain point of time in the future will be equivalent to the sum of rooms booked at the current moment of time and average change in bookings within the analyzable points of time.

Based on data on financial activities of 33 machine building plants and principle component analysis (PCA), A.A. Mitsel' and E.V. Telipenko [4] evaluated the effect of various factors on corporate revenue (labor productivity, return on assets, inventory turnover, etc.). The regression equation can be used to predict revenue depending on performance indicators.

In their article E.O. Trusova, I.V. Baranova. N.A. Kulagina [5] forecast revenue of a company generating electricity and thermal power. The forecast was based on a regression equation, where the average heat season temperature and Consumer Price Index for paid services are exogenous variables.

S.O. Musienko proposed the model which refers to the amount of fixed asses, inventories, cash and accounts receivable to assess revenue of small businesses [6].

C. Hu, M. Chen, S.-L.C. McCain [7] attempt to predict the revenue of a restaurant in a casino using the method of moving average and exponential smoothing, regression model implying the seasonal and trend components, and multivariate regression (independent variables include the number of rooms occupied in the hotel, marketing events and dummy variable in accordance with a day of the week).

In their article V.S. Timofeeva, A.Yu. Kolesnikova [8] determine sales volume of retailers through the pace of purchases, which are typical of different types of buyers.
Revenue prediction is concerned in researches by I.V. Orlova, E.S. Filonova, S.V. Grigor'eva, N.V. Noakk, I.V. Nevolin, A.S. Tatarnikov [9-11].

Therefore, regression models are so frequently used for revenue prediction purposes. Indeed, there is no versatile model which would demonstrate the highest precision in all datasets. In this respect several models shall be considered for different tasks, with the most suitable one being chosen for the purpose.

A combination of several methods or models (thewisdom-of-the-crowd principle) is taken into consideration. This approach is employed in researches referred to herein [12-14].

Regression model also helps address other tasks, for example, when it is necessary to determine what conditions should be in place so that the analyzable indicator be equal to the target value [15].

This research focuses on short-term prediction of revenue of a fast food restaurant situated in a shopping mall.

Such revenue depends on human behavior, which is often spontaneous and driven by many factors (menu, price, location). These aspects are considered in proceedings by E.N. Myasnikova, N.V. Mordovchenkov, A. Laske, N. Cercone, J. Suanders [16-18].

For purposes of this research, we refer to data on daily revenue for a two years' time $(2015,2016)$.

Fig. 1 shows how revenue changes during two weeks. It demonstrates regular fluctuations due to an increase in customers at weekends as compared with business days. As the revenue analysis reveals, revenue on holidays may be considerably different from a dataset corresponding to a certain day of the week.

Fig. 2 indicates values of revenue on Monday. Relating to holidays, the two of them are evidently higher than the others (February 23 and March 9). Considering the way revenue changes, we predict the analyzable indicator on holidays and other days (non-holidays).

To forecast revenue on non-holidays, we examined three regression models ${ }^{1}$ :

- autoregressive model;

\footnotetext{
${ }^{1}$ Solomentseva E.S. [Regression models for revenue prediction]. Informatsionnye tekhnologii v nauke, upravlenii, sotsial'noi sfere i meditsine: materialy IV Mezhdunarodnoi nauchnoi konferentsii [Proc. Int. Sci. Conf. Information Technology in Science, Management, Social Sphere and Medicine]. Tomsk, TPU Publ., 2017, pp. 230-232.

URL: http://portal.tpu.ru/appnews/files/18083/ik_cbornik.pdf
} 
- season- and trend-specific model;

- trend model (formed per each day of the week).

The autoregressive model describes the dependence of the resultant indicators on the value at previous points of time. The $p$-model is expressed as follows ${ }^{2}$ :

$$
y_{t}=\beta_{0}+\beta_{1} y_{t-1}+\beta_{2} y_{t-2}+\ldots+\beta_{p} y_{t-p}+\varepsilon_{t} \text {, }
$$

where $y_{t}$ is a dependent variable at the $t$-time;

$\beta$ stands for regression parameters to be assessed;

$\varepsilon_{t}$ is closing error.

In the analyzable case revenue is a dependent value, with the $t$-time corresponding to the ordinal number of a day.

To assess $\beta$-parameters of the regression, we apply the least squares method. The first-, second- and seventh-order regression equation are expressed as follows:

$$
\begin{aligned}
& y_{t}^{(1)}=15,030.6+0.48 y_{t-1}+\varepsilon_{t} ; \\
& y_{t}^{(2)}=19,574.5+0.6100 y_{t-1}+0.2971 y_{t-2}+\varepsilon ; \\
& y_{t}^{(7)}=5,168.11+0.3369 y_{t-1}-0.1663 y_{t-2}+ \\
& +0.0315 y_{t-3}+0.0213 y_{t-4} 0.1182 y_{t-5}+ \\
& +0.2009 y_{t-6}+0.5187 y_{t-7}+\varepsilon_{t} .
\end{aligned}
$$

The resultant equations describe the dependence of revenue at the $t$-time on its value at previous moments of the time $t-1, t-2, t-7$.

The season- and trend-specific model can be presented in additive and multiplicative format. If seasonal fluctuations vary within a constant range, the additive model is used, while the multiplicative model works in case of variable range. In this case revenue variance within a week is regarded as seasonal.

In the analyzable dataset, the range of variance is permanent. Hence the additive model is applied:

$Y=S+T+E_{1}$

where $Y$ is estimated revenue;

$S$ is a seasonal component;

\footnotetext{
${ }^{2}$ Aivazyan S.A., Mkhitaryan V.S. Prikladnaya statistika i osnovy ekonometriki [Applied statistics and principles of econometrics]. Moscow, YUNITI Publ., 1998, 256 p.
}

$T$ is a trend component;

$E$ is a casual error of the model.

When the model is being built, the initial series is smoothed by the moving average method. Deviation between the resultant values and real revenue are determined.

The difference contributes to the formation of the seasonal component. Each day of the week is assigned the average deviation. Afterwards values are adjusted so that their sum be nil. Seasonal components of Monday, Tuesday, Wednesday, Thursday, Friday, Saturday and Sunday turned to be $-6,376.87,-7,346.91$, $-7,032.28,-5,243.63,-1,812.15,14,966.1$ and $12,985.3$ respectively.

Values of the seasonal components are subsequently deducted from initial values of revenue. Based on the resultant series, the trend equation is made.

Therefore, the trend component is as follows:

$T=33,676.82-14.67 t$.

The predicted revenue equals the sum of the trend and seasonal components.

The third model is constructed by grouping data by day of the week and forming the trend equation of each group:

$$
y_{t}^{(j)}=\beta_{0}+\beta_{1} t+\varepsilon_{t},
$$

where $j$ is the ordinal number of a day of the week ( 1 for Monday, 2 for Tuesday, etc.).

The resultant regression functions of each day of the week are as follows:

$$
\begin{aligned}
& y_{t}^{(1)}=26,763.53-90.45 t+\varepsilon_{t} ; \\
& y_{t}^{(2)}=31,777.25-73 t+\varepsilon_{t} ; \\
& y_{t}^{(3)}=40,555.31-80.01 t+\varepsilon_{t} ; \\
& y_{t}^{(4)}=54,273.54-93.95 t+\varepsilon_{t} ; \\
& y_{t}^{(5)}=64,171.88-88.45 t+\varepsilon_{t} ; \\
& y_{t}^{(6)}=135,222.8-178.43 t+\varepsilon_{t} ; \\
& y_{t}^{(7)}=110,830.4-114,34 t+\varepsilon_{t} .
\end{aligned}
$$

A function is chosen in line with a day of the week at the predicted moment of time.

Please cite this article as: Gribanova E.B., Solomentseva E.S. Models to Forecast Revenue of Fast Food Restaurants. 
To assess the accuracy of the regression models, we involve the mean error formula:

$$
\delta=\frac{1}{n} \sum_{t=1}^{n}\left|y_{t}-y_{t}^{*}\right|,
$$

where $n$ is sample size;

$y_{t} \quad$ is real value of revenue at the $t$-time;

$y_{t}^{*}$ is predicted revenue at the $t$-time.

Table 1 presents values of errors of the analyzable models and F-test. All the equations are statistically meaningful for a 99-percent confidence interval. The least error is recorded in case of the seventh-order autoregressive model.

It is more difficult to predict revenue on holidays due to the following reasons:

- revenue is not the same on different holidays (January 25, March 8, etc.), i.e. the same equation is inapplicable to all the holidays;

- there are scarce data on revenue on a particular holiday. For example, data on the analyzable company's performance are available for two years' time only. Hence two values of revenue are known for each holiday;

- long time interval between holidays (year), during which revenue trends and level may well change;

- revenue may fit values of a day during the week of the holiday, or be different from them.

For revenue prediction in this case, we use an approach based on data grouping by day of the week, and outlier analysis. Outlier shall mean value, which strongly deviates from other values of the dataset. As depicted in Fig. 2, revenue on holiday pertains to a higher level, that is outlier. Outliers are detected through statistical procedures, with one of them being based on the assessment of quartiles Q1 and Q3. A value is qualified as outlier if it does fall within the interval:

$$
\left[Q_{1}-1.5\left(Q_{3}-Q_{1}\right), Q_{3}+1.5\left(Q_{3}-Q_{1}\right)\right] \text {. }
$$

Before such verification starts, all the values of revenue on holiday are taken away from the sample.

Tables 2 and 3 present the outcome of outlying test of some values of revenue on holidays. Outliers are seen to include only those values of revenue that relate to business days. It signifies that there is a certain threshold value of the fast food restaurant's revenue, which depends on the number of people serviced that day. This number constitutes a certain limit that results from the time it takes to cook the ordered meal, and capacity of the dining space. In other words, revenue on holiday is not higher than on weekends.

To predict revenue on holiday of the current year on the year-on-year basis, we use a dataset grouped by day of the week. The group (day of the week) can be chosen in several ways.

1. A day of the week when the sum of squared deviation of revenue from its value on holiday the previous year is minimum:

$$
\sum_{i=1}^{n}\left(x_{i}^{(j)}-y_{h}\right)^{2} \rightarrow \min ,
$$

where $n$ is the number of elements in the j-group;

$x_{i}^{(j)}$ stands for values of revenue in the $j$-group (training set);

$y_{h}$ stands for values of revenue on holidays the previous year;

$j$ is the group number corresponding to a day of the week.

2. A day of the week which is holiday the current year.

3. A day of the week which was holiday the previous year.

4. A day of the week when the sum of squared deviation of revenue from its values on holidays is minimum:

$$
\sum_{h=1}^{m} \sum_{i=1}^{n}\left(x_{i}^{(j)}-y_{h}\right)^{2} \rightarrow \min ,
$$

where $m$ is the number of holidays.

In revenue forecasts two scenarios are possible:

- value will not be outlier (for the rest of revenue values falling onto a day of the week when there is a holiday);

- value will be outlier.

In the first case scenario, the regression is build on the data on the day of the week, which is holiday the current year (the second option of data selection is applied, Fig. 3). Thus, we use the approach considered in forecast of non-holidays.

In the second case scenario, the option of data selection depends on the fact whether the value of revenue on holiday the previous year was outlier. In this case, three scenarios should be taken into consideration:

- the value of revenue on holiday the previous year was not outlier. For example, the holiday was Sunday 
the previous year, but it is a weekday the current year. Therefore, to forecast the respective value, it is necessary to apply the third option for data collection, using the data on the day of the week which was holiday the previous year;

- value of revenue on holiday turned out to be outlier the previous year. For example, the holiday takes place on a weekday the previous and current year. In this case, to predict the value, it is necessary to apply the first option of data collection, using the data on the day of the week when the sum of squared deviations of revenue on holiday the previous year is minimum;

- there are no data on revenue on holiday the previous year since the company started its operations after this point of time. Thus, to predict the value, the forth option of data collection should be applied, using the data on the day of the week when the sum of squared deviations of revenue from its value on holiday is minimum (if there are data on values of revenue on other holidays).

The paragraphs below show an example of revenue prediction for March 8, 2016. The value in 2015 is known, without being qualified as outlier. If the value is outlier the current year, it will be necessary to use the data on the day of the week which was holiday the previous year (Sunday). Built on the recent 24 values of revenue on Sunday (half year), the trend equation is expressed as follows:

$y_{t}=53,063.07-530.875 t$.

The predicted revenue is as follows:

$53,063.07-25 \cdot 530.875=$ RUB 39,791.18.
If the value of revenue is not outlier, it will be necessary to use the data on a day of the week which is holiday the current year (Tuesday). The resultant trend equation is expressed as follows:

$y_{t}=19,122.28+211.497 t$.

The predicted value of revenue will equal

$19,122.28+25 \cdot 211.497=$ RUB 24,409.74.

The real value of revenue was RUB 36,269 on March 8, 2016. In both options forecasting errors will be as follows:

$$
\mid 36,269 \text { - 39,791.18| = RUB 3,522.18; }
$$

$|36,269-24,409.74|=$ RUB 11,859.26.

Therefore, more precise forecast was made on the assumption that revenue is outlier. Fig. 4 shows errors arising in case of using the non-holiday prediction model to forecast the revenue on March 8.

Hence we made an attempt to forecast the fast food restaurant's revenue. Three regression models were applied to assess the value on non-holidays, i.e. the first-, second- and seventh-order autoregressive models, season- and trend-specific model and data grouping trend. All the equations proved to be statistically meaningful, with the least error being detected in case of the seventh-order autoregressive model. To predict revenue on holidays, we devised the value selection algorithm based on outlying analysis. As per the algorithm, we form two options of possible revenue by assuming that the value is or is not outlier. The article also provides an example of predicting revenue on holiday.

\section{Table 1}

$F$-test and errors

\begin{tabular}{lll}
\hline Type of model & Value of error & $\boldsymbol{F}$-test \\
\hline First-order autoregression & $8,081.41$ & 196.34 \\
\hline Second-order autoregression & $7,797.91$ & 137.18 \\
\hline Seventh-order autoregression & $5,722.87$ & 157.38 \\
\hline Season- and trend-specific model & $6,098.87$ & 898.56 \\
\hline Trends based on data grouping: & & \\
- Monday & $6,658.41$ & 7.9 \\
- Tuesday & $5,412.12$ & 7.24 \\
- Wednesday & $5,869.1$ & 7.27 \\
- Thursday & $6,298.24$ & 12.39 \\
- Friday & $6,736.03$ & 11.3 \\
- Saturday & $8,070.73$ & 23.66 \\
- Sunday & $8,168.66$ & 10.57 \\
\hline
\end{tabular}

\section{Source:Authoring}

Please cite this article as: Gribanova E.B., Solomentseva E.S. Models to Forecast Revenue of Fast Food Restaurants. 
Table 2

Outlying cases in 2015

\begin{tabular}{llllllll}
\hline Indicator & January 25 & February 23 & March $\mathbf{8}$ & May 1 & May 9 & June 12 & April 4 \\
\hline Day of week & Sunday & Monday & Sunday & Friday & Saturday & Friday & Wednesday \\
\hline Outlying & No & No & No & No & No & Yes & Yes \\
\hline
\end{tabular}

Source:Authoring

Table 3

Outlying cases in 2016

\begin{tabular}{llllllllll}
\hline Indicator & January 1 & January $\mathbf{7}$ & January 25 & February 23 & March $\mathbf{8}$ & May 1 & May $\mathbf{9}$ & June 12 & November 4 \\
\hline Day of week & Monday & Thursday & Monday & Tuesday & Tuesday & Sunday & Monday & Sunday & Friday \\
\hline Outlying & No & Yes & No & Yes & Yes & No & No & No & No \\
\hline
\end{tabular}

Source:Authoring

Figure 1

Changes in the fast food restaurant's revenue for two weeks, RUB

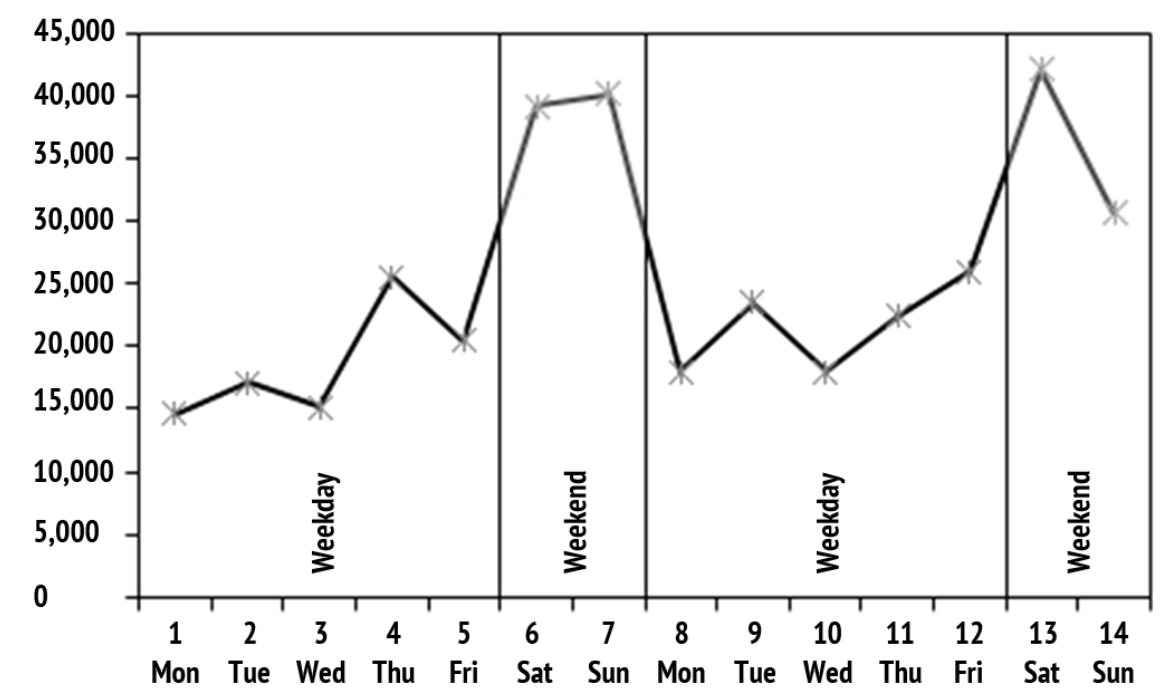

Source:Authoring 
Figure 2

The fast food restaurant's revenue on Monday, RUB

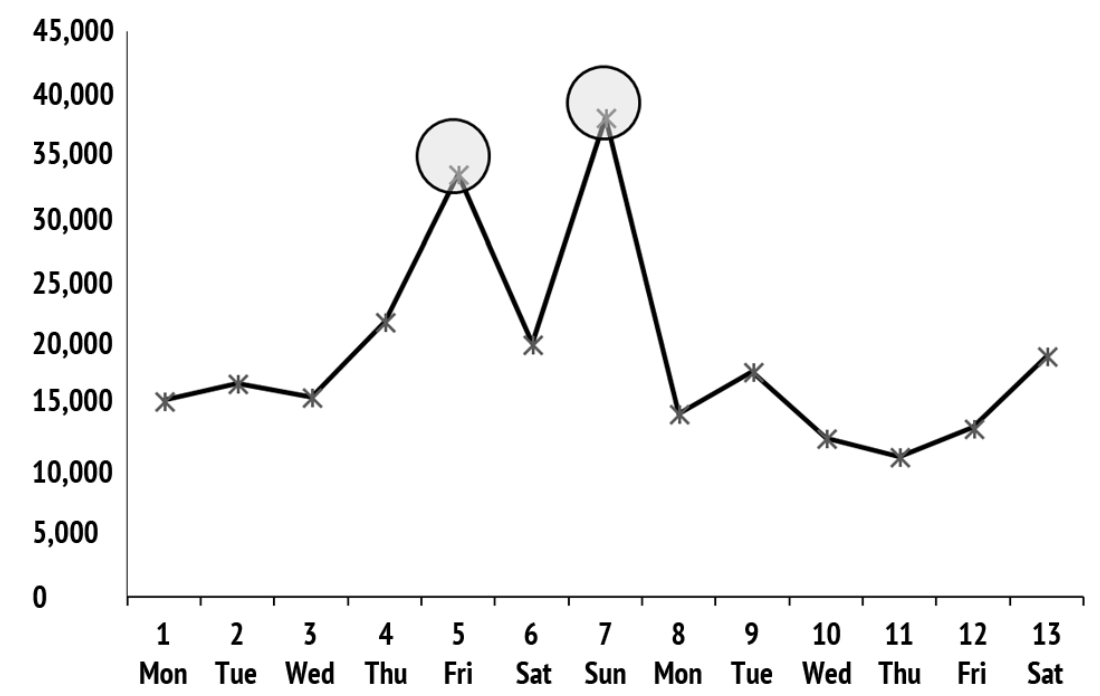

Source:Authoring

\section{Figure 3}

The data selection algorithm for revenue prediction

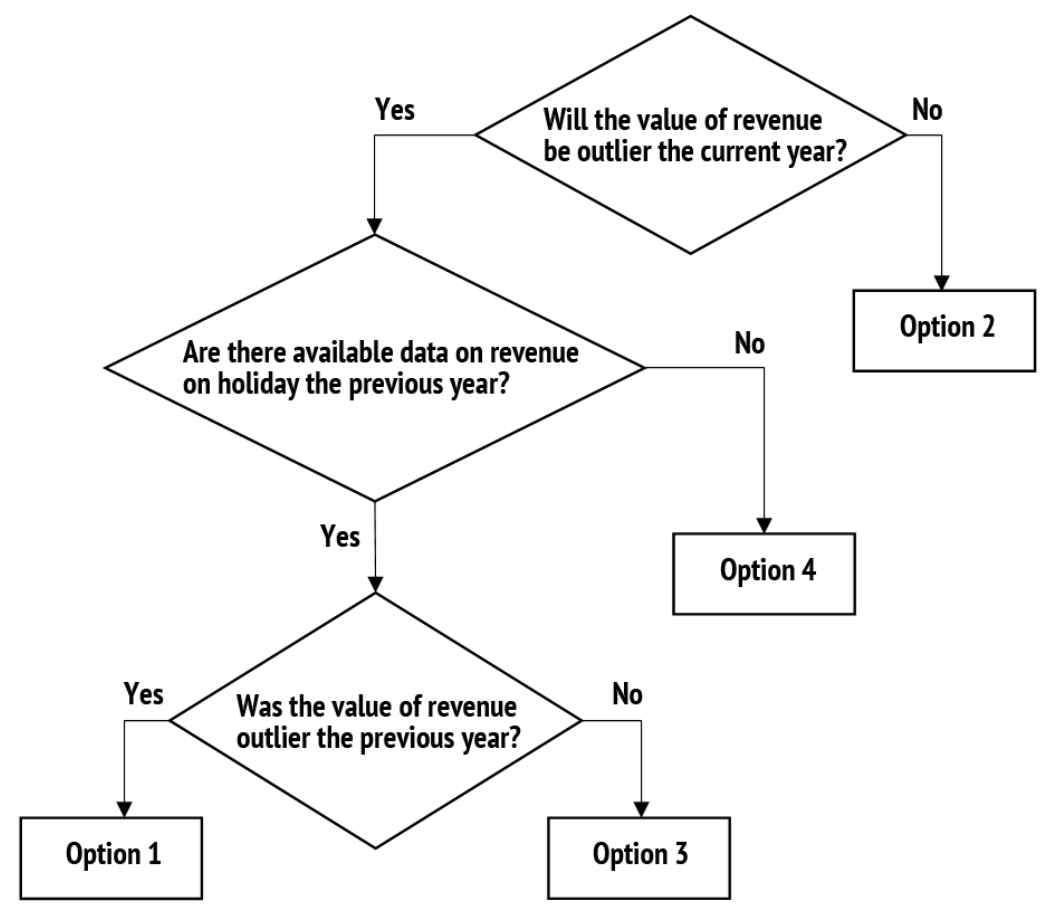

Source:Authoring 
Figure 4

Values of errors

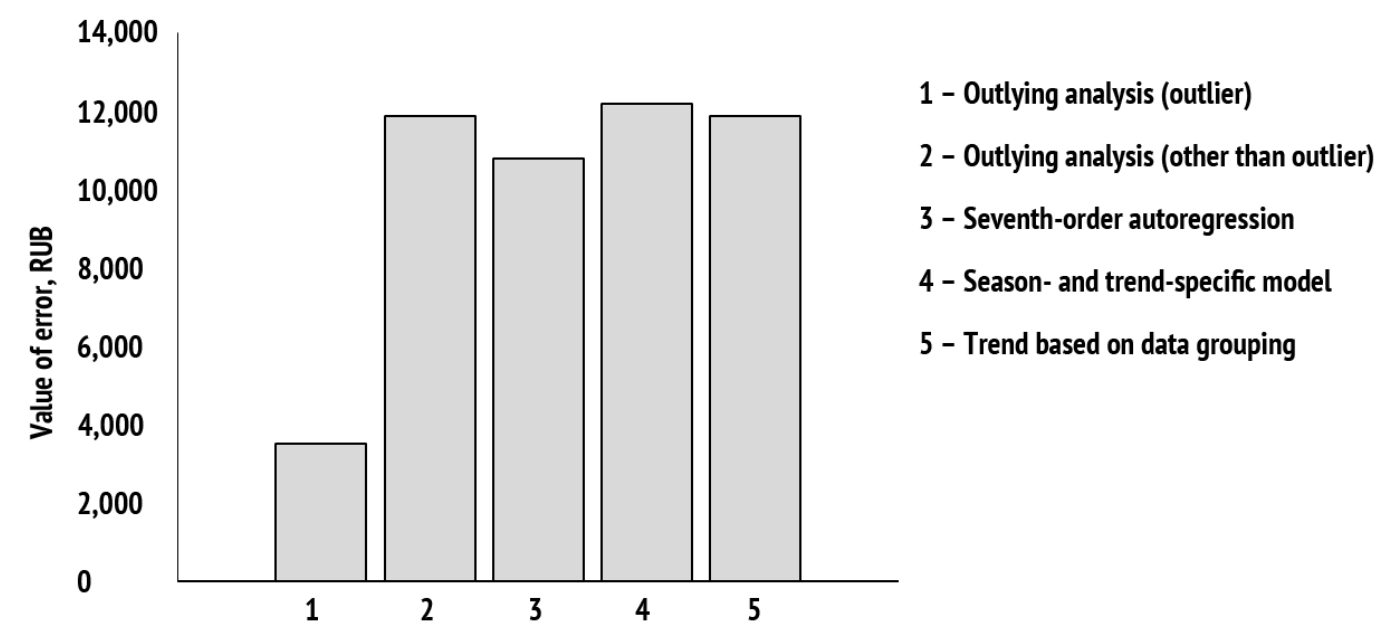

Source:Authoring

\section{References}

1. Lyubushin N.P., Babicheva N.E. [Analyzing the approaches to assess and forecast sales revenue subject to a seasonal component]. Ekonomicheskii analiz: teoriya i praktika = Economic Analysis: Theory and Practice, 2004, no. 6, pp. 6-16. URL: https://cyberleninka.ru/article/v/analiz-podhodov-k-otsenke-i-prognozirovaniyuvyruchki-ot-prodazh-s-uchetom-sezonnoy-sostavlyayuschey (In Russ.)

2. Odiyako N.N., Golodnaya N.Yu. [The use of the additive and multiplicative models forecasting]. Ekonomika $i$ predprinimatel'stvo = Journal of Economy and Entrepreneurship, 2013, no. 12-1, pp. 667-674. (In Russ.)

3. Weatherford L.R., Kimes S.E. A Comparison of Forecasting Methods for Hotel Revenue Management. International Journal of Forecasting, 2003, vol. 19, iss. 3, pp. 401-415.

URL: https://doi.org/10.1016/S0169-2070(02)00011-0

4. Mitsel' A.A., Telipenko E.V. [Assessing the impact of indicators of financial-economic activity of enterprise revenues from sales]. Ekonomicheskii analiz: teoriya i praktika = Economic Analysis: Theory and Practice, 2011, no. 27, pp. 57-64. URL: https://cyberleninka.ru/article/v/otsenka-vliyaniya-pokazateley-finansovohozyaystvennoy-deyatelnosti-predpriyatiya-na-vyruchku-ot-realizatsii-produktsii (In Russ.)

5. Trusova E.O., Baranova I.V., Kulagina N.A. [Assessment of influence of external factors on revenue of the organization by means of econometric model]. Sibirskaya finansovaya shkola = Siberian Financial School, 2017, no. 2, pp. 84-86. (In Russ.)

6. Musienko S.O. [Financial analysis and forecasting of the results of small businesses performance based on regression model]. Aktual'nye problemy ekonomiki i prava = Actual Problems of Economics and Law, 2017, no. 1, pp. 18-33. (In Russ.)

7. Hu C., Chen M., McCain S.-L.C. Forecasting in Short-Term Planning and Management for a Casino Buffet Restaurant. Journal of Travel \& Tourism Marketing, 2004, vol. 16, iss. 2-3, pp. 79-98. URL: https://doi.org/10.1300/J073v16n02_07

8. Timofeev V.S., Kolesnikova A.Yu. [Retail Sales Forecasting]. Ekonomika i matematicheskie metody = Economics and Mathematical Methods, 2009, no. 3, pp. 48-63. (In Russ.) 
9. Orlova I.V., Filonova E.S. [The Choice of Exogenous Factors in the Regression Model with Multicollinearity in the Data]. Mezhdunarodnyi zhurnal prikladnykh i fundamental'nykh issledovanii = International Journal of Applied and Fundamental Research, 2015, no. 5-1, pp. 108-116. (In Russ.)

10. Grigor'eva S.V. [Econometric analysis of financial condition of road transport companies]. Voprosy ekonomiki $i$ prava $=$ Problems of Economics and Law, 2012, no. 6, pp. 135-138. (In Russ.)

11. Noakk N.V., Nevolin I.V., Tatarnikov A.S. [Methods to forecast revenues from renting movies]. Finansovaya analitika: problemy i resheniya = Financial Analytics: Science and Experience, 2012, no. 48, pp. 17-24. URL: https://cyberleninka.ru/article/v/metodika-prognozirovaniya-vyruchki-ot-prokata-kinofilmov (In Russ.)

12. Ekmiş M.A., Hekimoğlu M., Atak Bülbül B. Revenue Forecasting Using a Feed-Forward Neural Network and ARIMA Model. Sigma Journal of Engineering and Natural Sciences, 2017, vol. 8, iss. 2, pp. 129-134.

13. Terui N., Dijk H. Combined Forecasts from Linear and Nonlinear Time Series Models. International Journal of Forecasting, 2002, vol. 18, iss. 3, pp. 421-438. URL: https://doi.org/10.1016/S0169-2070(01)00120-0

14. Zhang G. Time Series Forecasting Using a Hybrid ARIMA and Neural Network Model. Neurocomputing, 2003, vol. 50, pp. 159-175. URL: https://doi.org/10.1016/S0925-2312(01)00702-0

15. Gribanova E.B., Tugar-ool P.E. [The method for solving inverse problems of economic analysis using statistical data]. Korporativnye finansy, 2017, no. 3, pp. 111-120. (In Russ.) URL: https://cfjournal.hse.ru/article/view/7214/8129

16. Myasnikova E.N. [Formation of demand at restaurant business enterprises]. Nauchnyi vestnik MGIIT = Scientific Bulletin MSIIT, 2012, no. 4, pp. 26-31. (In Russ.)

17. Mordovchenkov N.V., Sidyakova V.A. [Definition of quality of services on means of marketing researches of restaurants]. Azimut nauchnykh issledovanii: ekonomika i upravlenie = The Azimuth of Scientific Research: Economics and Management, 2015, no. 1, pp. 114-118. (In Russ.)

18. Lasek A., Cercone N., Suanders J. Restaurant Sales and Customer Demand Forecasting: Literature Survey and Categorization of Methods. In: Smart City $360^{\circ}$ - First EAI International Summit, Bratislava, Slovakia and Toronto, Canada, October 13-16, 2015. Revised Selected Papers. Springer International Publishing, 2016, pp. 479-491. URL: https://doi.org/10.1007/978-3-319-33681-7_40

\section{Conflict-of-interest notification}

We, the authors of this article, bindingly and explicitly declare of the partial and total lack of actual or potential conflict of interest with any other third party whatsoever, which may arise as a result of the publication of this article. This statement relates to the study, data collection and interpretation, writing and preparation of the article, and the decision to submit the manuscript for publication. 